\title{
Myeloid Malignancies
}

\section{Christophe Ferrand and Alessandro Rambaldi}

In addition to chemotherapy, which remains the basic treatment, the treatment panel for acute myeloid leukaemia (AML) has expanded considerably in recent years. Clinicians now have a large choice of therapies: targeted therapies (anti-IDH1/2, anti-FLT3, and anti-BCL2 therapies, among others), drugs targeting epigenetic mechanisms, kinase inhibitors (FLT3, MAPK, and JAK2, etc.), immunotherapies (monoclonal antibodies linked or not to a toxin, dual/bispecific), and cellular immunotherapies. Moreover, despite its toxicities, allogeneic transplantation often remains an effective final therapeutic alternative. However, most patients are refractory or relapsed $(\mathrm{R} / \mathrm{R})$ after several lines of therapy. Thus, there is a clinical need in AML R/R patients, and CAR-T cells may be an option and can find a place in the treatment to reduce tumour burden and clinical evolution of the disease (Fig. 18.1, modified from Roussel et al. (2020)).

Several currently ongoing research programs aim to generate CAR-T cells against myeloid malignancies (Hofmann et al. 2019). However, the absence of a truly AML-specific marker generates remarkable uncertainty regarding the optimal antigens to target, and significant concern remains about off-target effects on normal haematopoiesis. The difficulty of obtaining successful manufacture of CAR-T cells from heavily pretreated patients has paved the way to investigation of different cell sources to build alternative platforms for cellular therapy.

\section{Ferrand}

EFS - INSERM UMR1098 RIGHT - UBFC, Molecular Onco Hematology Lab, EFS

Bourgogne Franche-Comté, Besançon, France

e-mail: christophe.ferrand@efs.sante.fr

\footnotetext{
A. Rambaldi (四)

Department of Oncology-Hematology, University of Milan and Azienda Socio Sanitaria

Territoriale Papa Giovanni XXIII, Bergamo, Italy

e-mail: alessandro.rambaldi@unimi.it
} 


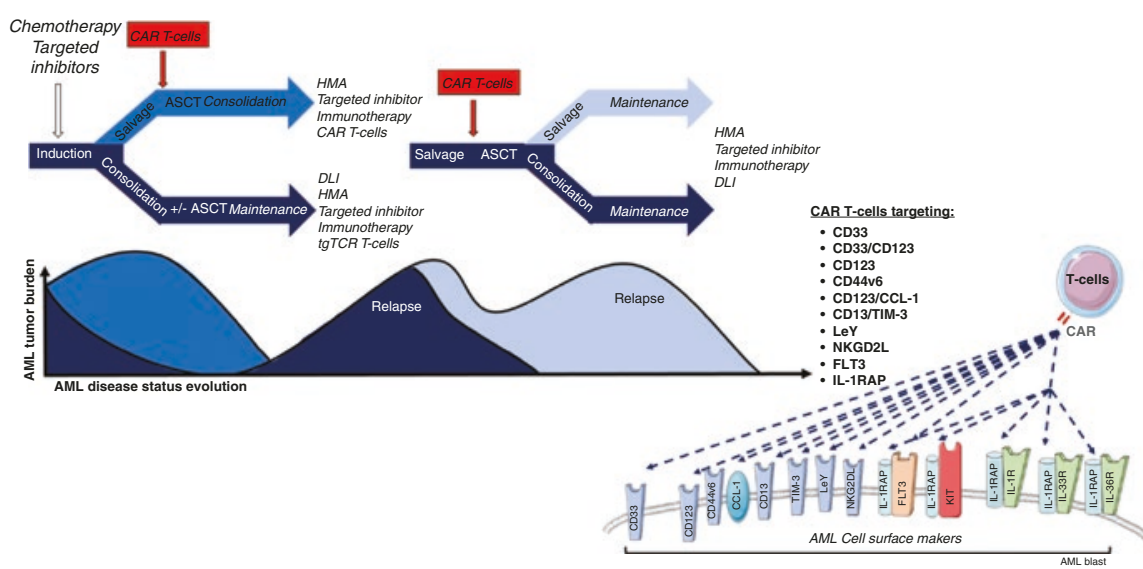

Fig. 18.1 Putative place of CAR-T cells in the AML treatment strategy. HMA hypomethylated agent, $D L I$ donor lymphocyte infusion, $t g T C R$ transgenic T cell receptor T cells, $A S C T$ allogeneic stem cell transplantation

\section{Single or Dual Antigen Targeting?}

CAR-T cells targeting CD33 and CD123 have already been investigated in early phase clinical trials. Unfortunately, these antigens do not avoid "on-target offtumour" effects, such as myelotoxicity and endothelial toxicity. For this reason, CAR-T cells directed against other surface proteins, such as CCL-1, CD44v6, FLT3, c-KIT (CD117), CD38, B7-H3 (also known as CD276), NKG2D, and IL-1RAP, are also under preclinical and clinical investigation (Table 18.1).

CD123 CAR-T cells induce haematopoietic toxicity but on a smaller scale than CD33 CAR-T cells, particularly following anti-CD123 single chain fragment variable (scFv) modifications (Mardiros et al. 2013; Gill et al. 2014; Thokala et al. 2016). Nevertheless, based on their expression on stem cells, CD123 CAR-T cells could be used as a myeloablative regimen before ASCT, thus representing an interesting strategy for treatment of R/R AML patients (Gill et al. 2014; Cummins and Gill 2019; Testa et al. 2019). Notably, IL-15 may enhance the anti-AML activity of CD123 CAR-T cells (Mu-Mosley et al. 2019). Targeting FLT3 or CD117 could be an attractive option, again in association with ASCT (Jetani et al. 2018; Myburgh et al. 2020). Targeting of the Lewis Y antigen and NKG2DL CAR-T cells has also been proposed, but phase 1 trials have shown short response durations, despite reduced toxicity (Ritchie et al. 2013; Driouk et al. 2019). CAR-T cells targeting CD44v6 mediate potent antitumour effects against AML while sparing normal haematopoietic stem cells (Casucci et al. 2013), and a clinical trial is currently ongoing. A potent effect on LSCs was observed with CAR-T cells targeting IL1RAP (Warda et al. 2019) with no apparent effect on healthy haematopoietic stem cells. Similar more specific antileukaemic activity was observed by targeting FLT3 and KIT mutations (Mitchell et al. 2018). Interestingly, targeting IL1RAP decreases IL-1, IL-6, IL-10, IL-13, IL-17, IL-22, IFN $\gamma$, and TNF $\alpha$ levels (Højen et al. 2019). The 
Table 18.1 CAR-T cell immunotherapies under investigation in AML (based on www.clinicaltrials.gov at $05 / 25 / 2020$ )

\begin{tabular}{|c|c|c|c|}
\hline CAR-T cells & Preclinical results & Status & Clinical trials \\
\hline \multirow[t]{2}{*}{ CD33 } & \multirow{2}{*}{$\begin{array}{l}\text { Myeloablative, ASCT } \\
\text { requirement }\end{array}$} & Phase 1 & NCT03126864 \\
\hline & & Phase $1 / 2$ & NCT03971799, NCT01864902 \\
\hline \multirow[t]{2}{*}{ CD123 } & \multirow[t]{2}{*}{$\begin{array}{l}\text { Myeloablative, ASCT } \\
\text { requirement }\end{array}$} & Phase 1 & $\begin{array}{l}\text { NCT03796390, NCT03585517, } \\
\text { NCT03114670, NCT03766126, } \\
\text { NCT04014881, NCT0319027,, } \\
\text { NCT02159495, NCT04230265, } \\
\text { NCT04318678, NCT03672851 }\end{array}$ \\
\hline & & Phase $1 / 2$ & $\begin{array}{l}\text { NCT04272125, NCT04265963, } \\
\text { NCT04109482, NCT03556982 }\end{array}$ \\
\hline CCL-1 & AML and HSC targeting & Phase 1 & NCT04219163 \\
\hline CD38 & AML targeting & Phase $1 / 2$ & NCT04351022 \\
\hline CD44v6 & AML targeting & Phase $1 / 2$ & NCT04097301 \\
\hline FLT3 & $\begin{array}{l}\text { Myeloablative, ASCT } \\
\text { requirement }\end{array}$ & Phase 1 & NCT03904069 \\
\hline KIT (CD117) & $\begin{array}{l}\text { Myeloablative, ASCT } \\
\text { requirement }\end{array}$ & Preclinical & NCT03473457 \\
\hline B7-H3 & HSC toxicity reduction & Preclinical & None \\
\hline CD13 TIM-3 & HSC toxicity reduction & Preclinical & None \\
\hline PD-1 & Antitumour enhancement & Preclinical & None \\
\hline Lewis Y & $\begin{array}{l}\text { Short duration of response, } \\
\text { few toxicities }\end{array}$ & Phase 1 & NCT01716364, no further study \\
\hline NKGD2L & $\begin{array}{l}\text { Short duration of response, } \\
\text { few toxicities }\end{array}$ & Phase 1 & NCT02203825, no further study \\
\hline IL1RAP & LSC targeting & Preclinical & NCT04169022 \\
\hline CD33/CD123 & AML and HSC targeting & Phase 1 & NCT04156256 \\
\hline CCL-1/CD123 & AML targeting & Phase $2 / 3$ & NCT03631576 \\
\hline CCL-1/CD33 & AML targeting & Phase 1 & NCT03795779 \\
\hline $\begin{array}{l}\text { CCL-1/CD33 } \\
\text { and/or CD123 }\end{array}$ & AML targeting & Phase $1 / 2$ & NCT04010877 \\
\hline $\begin{array}{l}\text { Muc1/CLL1/ } \\
\text { CD33/CD38/ } \\
\text { CD56/CD123 }\end{array}$ & AML targeting & Phase $1 / 2$ & NCT03222674 \\
\hline
\end{tabular}

Studies investigating T cell immunotherapies in AML. AML acute myeloid leukaemia, $L S C$ leukaemic stem cell, HSC haematopoietic stem cell, ASCT allogeneic stem cell transplantation

reduced production of IL-4, IL-6 and IL-10 and absence of IL-17 production (Warda et al. 2019) may in turn limit CAR-T cell cytokine release syndrome (CRS) and the immune effector cell-associated neurotoxicity syndrome (ICAN) associated with excessive production of IL-1 (Garcia Borrega et al. 2019). Notably, the reduction in IL-1 $\beta$, IL-6, and TNF $\alpha$ levels leads to decreased release of IL-10 and TGF $\beta$, which impair CAR-T cell functions (Epperly et al. 2020).

CAR-T cells simultaneously targeting CD33 and CD123 are also in development and exhibit pronounced antileukaemic activity (Petrov et al. 2018). Similarly, CD123 and CCL-1 compound CAR-T cells may be useful for active targeting of leukaemia stem cells (LSCs) (Morsink et al. 2018; Shang and Zhou 2019). 
Bispecific CD13-TIM-3 CAR-T cells (He et al. 2020) and B7-H3 CAR-T cells (Lichtman et al. 2018) showed reduced HSC toxicity. Moreover, the B7-H3 pancancer target was also studied in solid tumours (Waldman et al. 2020). Preliminary reports show that PD-1 inhibitors also regulate the CAR-T cell response, although few data are available. Furthermore, delivery of PD-1-blocking scFv CAR-T cells in preclinical investigations demonstrated interesting antitumour efficacy enhancement (Anonymous 2019). Several challenges remain to be overcome, as recently reported, and further investigations may provide a better understanding (Mardiana and Gill 2020).

\section{Molecular Engineering of the Chimeric Receptor and Alternative Cell Sources}

Beyond the selected target, optimizing the molecular engineering of the chimeric receptor remains crucial. CD33 4-1BBz CAR-T cells have shown antileukaemic activity and resistance to exhaustion with increasing central memory comportment (Li et al. 2018). An additional strategy that has been proposed to reduce haematopoietic toxicity is the use of a transiently expressed CART33 to induce self-limiting activity against AML cells (Kenderian et al. 2015). Another proposed strategy is to inactivate the CD33 gene in HSCs prior to transplantation to prevent CD33-induced haematopoietic toxicity of CAR-T cells (Kim et al. 2018).

In addition, to avoid or reduce the uncontrolled toxicity of expanding CAR-T cells, the use of the anti-CD52 antibody alemtuzumab or a suicide gene strategy based on CD20 protein coexpression in CD123 CAR-T cells has been proposed for subsequent anti-CD20 targeting with rituximab (Introna et al. 2000; Tasian et al. 2017).

Several clinical trials are currently evaluating the use of allogeneic CAR-T cells in haematologic malignancies, employing different effector cell types, such as NK cells (Daher and Rezvani 2021) or TCR-edited cells (Provasi et al. 2012), to limit GvHD and develop strategies to avoid the rejection of allogeneic cells. In this regard, the limited GvHD associated with the use of cytokine-induced killer (CIK) cells (Martino Introna et al. 2017) was confirmed in a phase I/IIa study in which B-ALL patients who relapsed after allogeneic transplantation were treated using CD19-specific CAR CIK cells (CARCIK-CD19) manufactured from a previous transplant donor (Magnani et al. 2020). Notably, this study provides evidence of the feasibility of employing a nonviral sleeping beauty transposon system to successfully produce CARCIK cell products starting from a small amount of donor-derived $\mathrm{PB}$, thus offering a valid alternative to viral vectors. The use of CAR-engineered CIK cells was also demonstrated to be effective for AML by characterizing the targeting of the two most validated AML molecules, CD33 and CD123, in vitro and in vivo (Tettamanti et al. 2013; Pizzitola et al. 2014; Arcangeli et al. 2017; Rotiroti et al. 2020). 


\section{Key Points}

- The primary challenge limiting the use of CAR-T cells in myeloid malignancies is the absence of an ideal antigen.

- Myeloid antigens are often coexpressed on normal haematopoietic stem/ progenitor cells (HSPCs).

- Myelotoxicity and endothelial toxicity can be overcome by "and/or" dual CAR targeting.

- Allogeneic CAR-T cells may be a future alternative.

\section{References}

Anonymous. Augmenting CAR-T cells with PD-1 blockade. Cancer Discov. 2019;9(2): 158. https://doi.org/10.1158/2159-8290.CD-NB2018-165.

Arcangeli S, Rotiroti MC, Bardelli M, Simonelli L, Magnani CF, Biondi A, Biagi E, Tettamanti S, Varani L. Balance of anti-CD123 chimeric antigen receptor binding affinity and density for the targeting of acute myeloid leukemia. Mol Ther. 2017;25(8):1933-45. https://doi.org/10.1016/j. ymthe.2017.04.017.

Borrega G, Jorge PG, Rüger MA, Onur ÖA, Shimabukuro-Vornhagen A, Kochanek M, Böll B. In the eye of the storm: immune-mediated toxicities associated with CAR-T cell therapy. HemaSphere. 2019;3(2):e191. https://doi.org/10.1097/HS9.0000000000000191.

Casucci M, di Robilant BN, Falcone L, Camisa B, Norelli M, Genovese P, Gentner B, et al. CD44v6targeted $\mathrm{T}$ cells mediate potent antitumor effects against acute myeloid leukemia and multiple myeloma. Blood. 2013;122(20):3461-72. https://doi.org/10.1182/blood-2013-04-493361.

Cummins KD, Gill S. Chimeric antigen receptor T-cell therapy for acute myeloid leukemia: how close to reality? Haematologica. 2019;104(7):1302-8. https://doi.org/10.3324/ haematol.2018.208751.

Daher M, Rezvani K. Outlook for new CAR-based therapies with a focus on CAR NK cells: what lies beyond CAR-engineered $\mathrm{T}$ cells in the race against cancer. Cancer Discov. 2021;11(1):45-58. https://doi.org/10.1158/2159-8290.CD-20-0556.

Driouk L, Gicobi J, Kamihara Y, Rutherford K, Dranoff G, Ritz J, Baumeister SHC. Chimeric antigen receptor T cells targeting NKG2D-ligands show robust efficacy against acute myeloid leukemia and T-cell acute lymphoblastic leukemia. Blood. 2019;134(Suppl 1):1930. https:// doi.org/10.1182/blood-2019-130113.

Epperly R, Gottschalk S, Paulina Velasquez M. A bump in the road: how the hostile AML microenvironment affects CAR-T cell therapy. Front Oncol. 2020;10:262. https://doi.org/10.3389/ fonc.2020.00262.

Gill S, Tasian SK, Ruella M, Shestova O, Li Y, Porter DL, Carroll M, et al. Preclinical targeting of human acute myeloid leukemia and myeloablation using chimeric antigen receptor-modified $\mathrm{T}$ cells. Blood. 2014;123(15):2343-54. https://doi.org/10.1182/blood-2013-09-529537.

He X, Feng Z, Ma J, Ling S, Cao Y, Gurung B, Wu Y, et al. Bispecific and split CAR-T cells targeting CD13 and TIM3 eradicate acute myeloid leukemia. Blood. 2020;135(10):713-23. https:// doi.org/10.1182/blood.2019002779.

Hofmann S, Schubert M-L, Wang L, He B, Neuber B, Dreger P, Müller-Tidow C, Schmitt M. Chimeric antigen receptor (CAR) T cell therapy in acute myeloid leukemia (AML). J Clin Med. 2019;8(2):200. https://doi.org/10.3390/jcm8020200.

Højen JF, Kristensen MLV, McKee AS, Wade MT, Azam T, Lunding LP, de Graaf DM, et al. IL-1R3 blockade broadly attenuates the functions of six members of the IL-1 family, reveal- 
ing their contribution to models of disease. Nat Immunol. 2019;20(9):1138-49. https://doi. org/10.1038/s41590-019-0467-1.

Introna M, Barbui AM, Bambacioni F, Casati C, Gaipa G, Borleri G, Bernasconi S, et al. Genetic modification of human T cells with CD20: a strategy to purify and lyse transduced cells with anti-CD20 antibodies. Hum Gene Ther. 2000;11(4):611-20. https://doi. org/10.1089/10430340050015798.

Introna M, Lussana F, Algarotti A, Gotti E, Valgardsdottir R, Mico C, Grassi A, et al. Phase II study of sequential infusion of donor lymphocyte infusion and cytokine-induced killer cells for patients relapsed after allogeneic hematopoietic stem cell transplantation. Biol Blood Marrow Transplant. 2017;23(12):2070-8. https://doi.org/10.1016/j.bbmt.2017.07.005.

Jetani H, Garcia-Cadenas I, Nerreter T, Thomas S, Rydzek J, Meijide JB, Bonig H, et al. CAR-T cells targeting FLT3 have potent activity against FLT3(-)ITD(+) AML and act synergistically with the FLT3-inhibitor crenolanib. Leukemia. 2018;32(5):1168-79. https://doi.org/10.1038/ s41375-018-0009-0.

Kenderian SS, Ruella M, Shestova O, Klichinsky M, Aikawa V, Morrissette JJD, Scholler J, et al. CD33-specific chimeric antigen receptor $\mathrm{T}$ cells exhibit potent preclinical activity against human acute myeloid leukemia. Leukemia. 2015;29(8):1637-47. https://doi.org/10.1038/ leu.2015.52.

Kim MY, Kyung-Rok Y, Kenderian SS, Ruella M, Chen S, Shin T-H, Aljanahi AA, et al. Genetic inactivation of CD33 in hematopoietic stem cells to enable CAR-T cell immunotherapy for acute myeloid leukemia. Cell. 2018;173(6):1439-1453.e19. https://doi.org/10.1016/j. cell.2018.05.013.

Li S, Tao Z, Yingxi X, Liu J, An N, Wang Y, Xing H, et al. CD33-specific chimeric antigen receptor $\mathrm{T}$ cells with different co-stimulators showed potent anti-leukemia efficacy and different phenotype. Hum Gene Ther. 2018;29(5):626-39. https://doi.org/10.1089/hum.2017.241.

Lichtman E, Hongwei D, Savoldo B, Ferrone S, Li G, Lishan S, Dotti G. Pre-clinical evaluation of B7-H3-specific chimeric antigen receptor T-cells for the treatment of acute myeloid leukemia. Blood. 2018;132(Suppl 1):701. https://doi.org/10.1182/blood-2018-99-113468.

Magnani CF, Gaipa G, Lussana F, Belotti D, Gritti G, Napolitano S, Matera G, et al. Sleeping beauty-engineered CAR-T cells achieve antileukemic activity without severe toxicities. J Clin Invest. 2020;130(11):6021-33. https://doi.org/10.1172/JCI138473.

Mardiana S, Gill S. CAR-T cells for acute myeloid leukemia: state of the art and future directions. Front Oncol. 2020;10:697. https://doi.org/10.3389/fonc.2020.00697.

Mardiros A, Dos Santos C, McDonald T, Brown CE, Xiuli Wang L, Budde E, Hoffman L, et al. $\mathrm{T}$ cells expressing CD123-specific chimeric antigen receptors exhibit specific cytolytic effector functions and antitumor effects against human acute myeloid leukemia. Blood. 2013;122(18):3138-48. https://doi.org/10.1182/blood-2012-12-474056.

Mitchell K, Barreyro L, Todorova TI, Taylor SJ, Antony-Debré I, Narayanagari S-R, Carvajal LA, et al. IL1RAP potentiates multiple oncogenic signaling pathways in AML. J Exp Med. 2018;215(6):1709-27. https://doi.org/10.1084/jem.20180147.

Morsink L, Walter R, Ossenkoppele G. Prognostic and therapeutic role of CLEC12A in acute myeloid leukemia. Blood Rev. 2018;34:26-33. https://doi.org/10.1016/j.blre.2018.10.003.

Mu-Mosley H, Ostermann LB, Muftuoglu M, Schober W, Patel NB, Vaidya A, Bonifant CL, Gottschalk S, Velasquez MP, Andreeff M. Transgenic expression of IL15 in CD123-specific BiTE-secreting engager T-cells results in improved anti-AML activity. Blood. 2019;134(Suppl 1):3917. https://doi.org/10.1182/blood-2019-125928.

Myburgh R, Kiefer JD, Russkamp NF, Magnani CF, Nuñez N, Simonis A, Pfister S, et al. Anti-human CD117 CAR-T cells efficiently eliminate healthy and malignant CD117-expressing hematopoietic cells. Leukemia. 2020;34(10):2688-703. https://doi.org/10.1038/s41375-020-0818-9.

Petrov JC, Wada M, Pinz KG, Yan LE, Chen KH, Shuai X, Liu H, et al. Compound CAR-T cells as a double-pronged approach for treating acute myeloid leukemia. Leukemia. 2018;32(6):1317-26. https://doi.org/10.1038/s41375-018-0075-3.

Pizzitola I, Anjos-Afonso F, Rouault-Pierre K, Lassailly F, Tettamanti S, Spinelli O, Biondi A, Biagi E, Bonnet D. Chimeric antigen receptors against CD33/CD123 antigens efficiently target 
primary acute myeloid leukemia cells in vivo. Leukemia. 2014;28(8):1596-605. https://doi. org/10.1038/leu.2014.62.

Provasi E, Genovese P, Lombardo A, Magnani Z, Liu P-Q, Reik A, Chu V, et al. Editing T cell specificity towards leukemia by zinc finger nucleases and lentiviral gene transfer. Nat Med. 2012;18(5):807-15. https://doi.org/10.1038/nm.2700.

Ritchie DS, Neeson PJ, Khot A, Peinert S, Tai T, Tainton K, Chen K, et al. Persistence and efficacy of second generation CAR-T cell against the LeY antigen in acute myeloid leukemia. Mol Ther. 2013;21(11):2122-9. https://doi.org/10.1038/mt.2013.154.

Rotiroti MC, Buracchi C, Arcangeli S, Galimberti S, Valsecchi MG, Perriello VM, Rasko T, et al. Targeting CD33 in chemoresistant AML patient-derived xenografts by CAR-CIK cells modified with an improved SB transposon system. Mol Ther. 2020;28(9):1974-86. https://doi. org/10.1016/j.ymthe.2020.05.021.

Roussel X, Daguindau E, Berceanu A, Desbrosses Y, Warda W, Neto M, da Rocha R, Trad ED, Deschamps M, Ferrand C. Acute myeloid leukemia: from biology to clinical practices through development and pre-clinical therapeutics. Front Oncol. 2020;10:599933. https://doi. org/10.3389/fonc.2020.599933.

Shang Y, Zhou F. Current advances in immunotherapy for acute leukemia: an overview of antibody, chimeric antigen receptor, immune checkpoint, and natural killer. Front Oncol. 2019;9:917. https:// doi.org/10.3389/fonc.2019.00917.

Tasian SK, Kenderian SS, Shen F, Ruella M, Shestova O, Kozlowski M, Li Y, et al. Optimized depletion of chimeric antigen receptor T cells in murine xenograft models of human acute myeloid leukemia. Blood. 2017;129(17):2395-407. https://doi.org/10.1182/blood-2016-08-736041.

Testa U, Pelosi E, Castelli G. CD123 as a therapeutic target in the treatment of hematological malignancies. Cancers. 2019;11(9):1358. https://doi.org/10.3390/cancers11091358.

Tettamanti S, Marin V, Pizzitola I, Magnani CF, Giordano GMP, Attianese EC, Maltese F, et al. Targeting of acute myeloid leukaemia by cytokine-induced killer cells redirected with a novel CD123-specific chimeric antigen receptor. Br J Haematol. 2013;161(3):389-401. https://doi. org/10.1111/bjh.12282.

Thokala R, Olivares S, Mi T, Maiti S, Deniger D, Huls H, Torikai H, et al. Redirecting specificity of $\mathrm{T}$ cells using the sleeping beauty system to express chimeric antigen receptors by mix-andmatching of VL and VH domains targeting CD123+ tumors. PLoS One. 2016;11(8):e159477.

Waldman AD, Fritz JM, Lenardo MJ. A guide to cancer immunotherapy: from T cell basic science to clinical practice. Nat Rev Immunol. 2020;20(11):651-68. https://doi.org/10.1038/ s41577-020-0306-5.

Warda W, Larosa F, Da Rocha MN, Trad R, Deconinck E, Fajloun Z, Faure C, et al. CML hematopoietic stem cells expressing IL1RAP can be targeted by chimeric antigen receptor-engineered T cells. Cancer Res. 2019;79(3):663-75. https://doi.org/10.1158/0008-5472.CAN-18-1078.

Open Access This chapter is licensed under the terms of the Creative Commons Attribution 4.0 International License (http://creativecommons.org/licenses/by/4.0/), which permits use, sharing, adaptation, distribution and reproduction in any medium or format, as long as you give appropriate credit to the original author(s) and the source, provide a link to the Creative Commons license and indicate if changes were made.

The images or other third party material in this chapter are included in the chapter's Creative Commons license, unless indicated otherwise in a credit line to the material. If material is not included in the chapter's Creative Commons license and your intended use is not permitted by statutory regulation or exceeds the permitted use, you will need to obtain permission directly from the copyright holder.

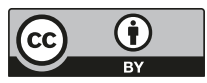

